\title{
Inter-rater agreement of the triagesystem RETTS-HEV
}

\author{
Louise Nissen $^{1 *}$, Hans Kirkegaard ${ }^{2}$, Noel Perez ${ }^{1}$, Ulf Hørlyck' ${ }^{1}$ Louise Pape $^{3}$ \\ From Proceedings of the 5th Danish Emergency Medicine Conference \\ Aarhus, Denmark. 18-19 April 2013
}

\section{Background}

The purpose of this study was to evaluate the inter-rater agreement among nurses using the triage system REETS- HEV (rapid emergency triage and treatment system-hospitalsenheden vest) in a Danish ED.

The use of triage systems in Denmark has recently been implemented together with structural changes in hospital organization. Testing and evaluation is therefore needed. The REETS-HEV is a five scale triage system being used in the Emergency department (ED) of Herning, Denmark since May 2010. The ED is semi-large with 29,000 annual visits.

\section{Methods}

Consecutive patients presenting to the ED were assessed by both a duty and study nurse using REETS-HEV. Nurses did not receive training prior to the study. 146 patients were enrolled and a blinded, paired and simultaneous triage was conducted independently to evaluate inter-rater agreement using Fleiss kappa.

\section{Results}

A total of 155 patients were triaged over a 10 day period and complete data were available for 146 patients. We found the overall agreement to be good (Fleiss kappa $0.60(0.48 ; 0.72))$. The kappa estimate was higher for the group of patients needing immediate attention $(0.83$ $(0.18 ; 1.47))$.

\section{Conclusion}

The study demonstrated good inter-rater agreement between two independent observers not receiving any new triage training prior to the study.

* Correspondence: louisenissen84@gmail.com

${ }^{1}$ Emergency Department, Regionshospital Herning hospital, Denmark

Full list of author information is available at the end of the article
Authors' details

${ }^{1}$ Emergency Department, Regionshospital Herning hospital, Denmark. ${ }^{2}$ Research Center for Emergency Medicine, Aarhus University Hospital, Denmark. ${ }^{3}$ Dept. of Occupational Medicine,Regional Hospital Herning, Denmark.

Published: 9 September 2013

doi:10.1186/1757-7241-21-S2-A32

Cite this article as: Nissen et al:: Inter-rater agreement of the

triagesystem RETTS-HEV. Scandinavian Journal of Trauma, Resuscitation and Emergency Medicine 2013 21(Suppl 2):A32.
Submit your next manuscript to BioMed Central and take full advantage of:

- Convenient online submission

- Thorough peer review

- No space constraints or color figure charges

- Immediate publication on acceptance

- Inclusion in PubMed, CAS, Scopus and Google Scholar

- Research which is freely available for redistribution
C Biomed Central 